\title{
Lick rates in gerbils
}

\author{
ROBERT W. SCHAEFFER \\ Auburn University, Auburn, Alabama 36830 \\ and \\ MIKE DAVID \\ Napa State Hospital, Napa, Calif. 94558
}

\begin{abstract}
Lick rates in infant and adult gerbils were measured for water under 12,24 , and $48 \mathrm{~h}$ of deprivation, and for $4 \%, 16 \%$, and $32 \%$ sucrose solutions, under $24 \mathrm{~h}$ of deprivation. Mean lick rates were found to be independent of sex, level of deprivation, and fluid consumed. Mean lick rates were affected by the age of the Ss. Infant gerbils, which initially licked at lower rates than the adult Ss, developed the same lick rates as adults as they matured. Possible implications of this finding for neurophysiological research were discussed.
\end{abstract}

There is a substantial body of evidence which indicates that lick rates in some mammals are stable and independent of age, sex, state of deprivation, or the type of fluid being drunk by the animal. Adolph (1939), in his work with fistulous dogs, observed that regardless of conditions, his dogs "gulped" at a rate between 164 and 190 "gulps"/min. If these "gulps" are topographically equivalent to licking or lapping behaviors, Adolph's observations suggest that the dog drinks at the relatively constant rate of about 3 licks/sec. These data are essentially equivalent to the dog lick rate data obtained by Smith (1951).

A number of experiments with rats as Ss demonstrate that this animal licks at the rate of approximately 6 licks/sec, regardless of the type of fluid drunk, age or sex of the Ss, or state of fluid deprivation. These experiments also indicate that lick rates obtained in the first few seconds of each test session are slightly elevated relative to the rates obtained in the remainder of the session (Goodrich, 1960; Schaeffer \& Premack, 1961; Stellar \& Hill, 1952).

Schaeffer \& Huff (1965) have demonstrated that lick rates in cats vary only between 3.4 and 4.5 licks/sec, regardless of fluids drunk, age or sex of the Ss, or state of fluid deprivation. Schaeffer and Huff also suggest that lick rates are genetically determined and that each species may have a characteristic lick rate which might potentially distinguish it behaviorally from other species. The present experiment was undertaken to determine characteristic lick rates in the Mongolian gerbil (Meriones unguiculatus), a laboratory animal which has become relatively popular during the past several years.

\section{METHOD}

Six adult male and six adult female Mongolian gerbils, about 200 days of age, and four male and two female infant Mongolian gerbils, 26 days of age, served as Ss. Prior to testing, the infant gerbils had received all of their fluids via nursing. Thus, prior to testing, the infants were raised without any opportunity to drink from any artificial drinking devices.

Throughout the experiment, each gerbil was individually housed in a cage constructed of .385-in. Plexiglas. Each cage was $8 \mathrm{in}$. long, $8 \mathrm{in}$. Iwide, and $8 \mathrm{in}$. high. Each cage was fitted with a lid of hardware cloth and a Plexiglas floor. Approximately 1 in. of Pel-e-cell and shredded paper were used as bedding material. These home cages also served as the experimental chambers.

A 2-in.-square platform of hardware cloth was attached to one side of the cage and positioned so that the top of the platform was about 2 in. above the cage floor. A small hole was bored in the Plexiglas wall, 1 in. above the platform, into which a standard Wahmann small-bore stainless steel drinking tube was positioned. The exterior of the drinking tube was insulated with Formvar, an insulating material used to insulate electrical transformers. This insulation prevented general body contacts from activating the drinkometer circuit, and insured that only tongue-fluid contacts would activate the drinkometer circuit.

The platform and the drinking tube were connected to the two sides of a standard drinkometer circuit. Tongue-fluid contacts activated the drinkometer circuit, which in turn activated the pen elements of an Esterline Angus digital operations recorder, which produced a permanent record of each lick. The speed of the recorder was set at $0.5 \mathrm{in} . / \mathrm{sec}$.

All adult Ss were given 1 day of ad lib water to permit them to become accustomed to the cage and to the location of the drink tube, then were placed on $48 \mathrm{~h}$ of water deprivation. Infant Ss were given no ad lib water, but were simply placed on $48 \mathrm{~h}$ of water deprivation on the first test day. This $48-\mathrm{h}$ initial deprivation period was used because previous work in our laboratory had indicated that (a) infant gerbils drink so seldom that there is little chance they will drink in a session preceded by less than $48 \mathrm{~h}$ of fluid deprivation, and (b) we felt it was important to use procedures that would insure that the Ss licked the very first time they encountered fluid in a mechanical reservoir.

Lick rates of water were obtained after 48,24 , and $12 \mathrm{~h}$ of water deprivation, in that order. Lick rates for sucrose were obtained subsequent to the water tests, under $24 \mathrm{~h}$ of deprivation. Lick rates for $4 \%, 16 \%$, and $32 \%$ (by weight) sucrose solutions obtained, in that order. Ss were given 24-h access to water prior to the first sucrose test and immediately following each sucrose solution test.

\section{RESULTS AND DISCUSSION}

Lick rates were determined using the methods employed by Schaeffer \& Huff (1965). These were (1) momentary lick rates based on a second-by-second analysis of the licks recorded, (2) mean lick rates within sustained bursts of at least 5-sec durations, (3) changes in lick rates within sustained bursts, and (4) changes in lick rates within each entire session.

As can be seen in Tables 1 and 2, the mean lick rates per second for the adult male and female gerbils varied only between 5.4 and 7.2 licks/sec. Mean lick rates obtained from bursts of $5 \mathrm{sec}$ or longer for these Ss varied only between 5.8 and 7.0 licks/sec. No adult S's momentary lick rate exceeded a maximum of 9.0 licks $/ \mathrm{sec}$, or fell below a minimum of 5.0 licks $/ \mathrm{sec}$. The modal momentary lick rates for the adult male and adult female gerbils were either 6.0 or 7.0 licks $/ \mathrm{sec}$. These 
Table 1

Mean Lick Rates and Lick Ranges for Adult Male Gerbils for 1-Sec Measures and Lick Bursts of 5 Sec or More*

\begin{tabular}{|c|c|c|c|c|c|c|c|c|}
\hline \multirow[b]{2}{*}{$\mathrm{S}$} & \multirow[b]{2}{*}{ Measure } & \multicolumn{3}{|c|}{ Water } & \multicolumn{3}{|c|}{ Sucrose } & \multirow[b]{2}{*}{ Ranga } \\
\hline & & 12 & 24 & 48 & + & $16^{\circ}$ & 32 & \\
\hline $\mathbf{M 1}$ & $\begin{array}{l}1 \text { Sec } \\
\text { Burst }\end{array}$ & $\begin{array}{l}5.4 \\
5.8\end{array}$ & $\begin{array}{l}6.7 \\
6.5\end{array}$ & $\begin{array}{l}6.4 \\
6.2\end{array}$ & $\begin{array}{l}6.5 \\
6.9\end{array}$ & $\begin{array}{l}6.5 \\
6.4\end{array}$ & $\begin{array}{l}6.4 \\
6.4\end{array}$ & $\begin{array}{l}5 .(1-8.1 \\
5.6-^{-} .1\end{array}$ \\
\hline 112 & $\begin{array}{l}1 \text { Sec } \\
\text { Burst }\end{array}$ & $\begin{array}{l}6.4 \\
6.5\end{array}$ & $\begin{array}{l}6.4 \\
0.5\end{array}$ & $\begin{array}{l}6.2 \\
6.1\end{array}$ & $\begin{array}{l}6.0 \\
6.0\end{array}$ & $\begin{array}{l}5.7 \\
5.8\end{array}$ & $\begin{array}{l}6.0 \\
6.0\end{array}$ & $\begin{array}{l}\Sigma 0.80 \\
5.6-6.9\end{array}$ \\
\hline 113 & $\begin{array}{l}1 \text { Sec } \\
\text { Burst }\end{array}$ & $\begin{array}{l}6.3 \\
6.4\end{array}$ & $\begin{array}{l}6.9 \\
6 . ?\end{array}$ & $\begin{array}{l}6.11 \\
6.5\end{array}$ & $\begin{array}{l}6.8 \\
6.9\end{array}$ & $\begin{array}{l}6.7 \\
6.7\end{array}$ & 6.7 & $\begin{array}{l}6 .(1-8.0 \\
6.2-7.1\end{array}$ \\
\hline $\mathrm{Mt}$ & $\begin{array}{l}1 \text { Sec } \\
\text { Burst }\end{array}$ & $\begin{array}{l}7.0 \\
7.0\end{array}$ & $\begin{array}{l}6.9 \\
6.9\end{array}$ & $\begin{array}{l}6.6 \\
6.4\end{array}$ & $\begin{array}{l}6.7 \\
6.6\end{array}$ & $\begin{array}{l}6.9 \\
6.7\end{array}$ & $\begin{array}{l}6.5 \\
6.3\end{array}$ & $\begin{array}{l}6.0-9.0 \\
6.0-7.7\end{array}$ \\
\hline II & $\begin{array}{l}1 \text { Sec } \\
\text { Burst }\end{array}$ & $\begin{array}{l}6.3 \\
6.4\end{array}$ & 6.5 & $\begin{array}{l}6.3 \\
6.3\end{array}$ & $\begin{array}{l}6.3 \\
6.2\end{array}$ & $\begin{array}{l}5.5 \\
6.4\end{array}$ & $\begin{array}{l}5.9 \\
6.0\end{array}$ & $\begin{array}{l}5.0-8.0 \\
5.0-6.6\end{array}$ \\
\hline 116 & $\begin{array}{l}1 \text { Ses } \\
\text { Burst }\end{array}$ & $\begin{array}{l}7.0 \\
6.9\end{array}$ & $\begin{array}{l}6.8 \\
6.8\end{array}$ & $\begin{array}{l}6.5 \\
6.6\end{array}$ & $\begin{array}{l}6.7 \\
6.7\end{array}$ & $\begin{array}{l}6.5 \\
6.5\end{array}$ & $\begin{array}{l}6.7 \\
6.6\end{array}$ & $\begin{array}{l}6.0-8.0 \\
6.2-7.2\end{array}$ \\
\hline
\end{tabular}

* Data for water are shown as a function of hours of water deprivation. All sucrose solution data were collected under 27 h of water deprivation. All empty cells indicate $S$ did not drink under that condition.

bimodal values were found in all Ss and varied randomly within Ss. across trials. and across test conditions. The single exception to the bimodal values of 6.0 or 7.0 licks'sec was obtained from a male gerbil. S 5. The modal rate obtained for this $\mathrm{S}$ for the $16 \%$ and $32 \%$ sucrose solutions was 5 licks/sec. For all other solutions and all other test conditions. S 5 showed a bimodal lick rate of 6.0 or 7.0 .

Under all deprivation conditions. and for the 4\% sucrose solution. the adults ${ }^{\circ}$ lick rate in the first few minutes of each session tended to exceed by 1 or 2 licks the mean rate for the entire session. Similarly. the initial lick rate in sustained lick bursts was 1 or 2 licks/sec faster than the mean lick rate for the entire burst. and as much as 3 licksisec faster than the lick rate observed in the terminal second of sustained lick bursts. When tested with the $16 \%$ and $32 \%$ sucrose solutions, however. all adult male and female Ss exhibited (a) an initial lick rate that was approximately 1 lick/sec less than the mean lick rate obtained for the entire session, and (b) no dramatic reduction in lick rates within lick bursts. These results suggest that. for the gerbil. sucrose solutions have an initial general inhibitory effect upon the lick reflex.

As can be seen in Table 3. the infant male and female gerbils all exhibited lick rates substantially lower than those that were found in the adult male and female gerbils. Mean lick rates per second for the infant gerbils varied between 5.2 and 6.0 licks/sec. Mean lick rates obtained in bursts of $5 \mathrm{sec}$ or more for these infant Ss varied between 5.1 and $6.4 \mathrm{licks} / \mathrm{sec}$. No infant Ss exceeded a maximum of 8.0 licks/sec or fell below a minimum of 4.0 licks/sec. Within-burst decrements in lick rates and within-session decrements in lick rates were comparable to the decrements in lick rates observed in the adult Ss.

An analysis of variance performed on the mean

Table 2

Mean Lick Rates and Lick Ranges for Adult Female Gerbils for 1-Sec Measures and Lick Bursts of 5 Sec or More

\begin{tabular}{|c|c|c|c|c|c|c|c|c|}
\hline \multirow[b]{2}{*}{$\mathrm{S}$} & \multirow[b]{2}{*}{ Measure } & \multicolumn{3}{|c|}{ Water } & \multicolumn{3}{|c|}{ Sucrose } & \multirow[b]{2}{*}{ Range } \\
\hline & & 12 & 24 & 48 & 4 & 16: & $32=$ & \\
\hline $\mathrm{F} 1$ & $\begin{array}{l}1 \mathrm{Sec} \\
\text { Burst }\end{array}$ & $\begin{array}{l}6.5 \\
6.5\end{array}$ & $\begin{array}{l}6.2 \\
6.2\end{array}$ & $\begin{array}{l}6.5 \\
6.4\end{array}$ & $\begin{array}{l}6.0 \\
6.0\end{array}$ & $\begin{array}{l}6.4 \\
6.4\end{array}$ & $\begin{array}{l}6.6 \\
6.6\end{array}$ & $\begin{array}{l}5.0-8.0 \\
5.9-7.0\end{array}$ \\
\hline $\mathrm{F} 2$ & $\begin{array}{l}1 \mathrm{Sec} \\
\text { Burst }\end{array}$ & $\begin{array}{l}6.1 \\
6.0\end{array}$ & $\begin{array}{l}6.7 \\
6.7\end{array}$ & $\begin{array}{l}6.8 \\
6.8\end{array}$ & $\begin{array}{l}6.2 \\
6.2\end{array}$ & $\begin{array}{l}6.0 \\
6.0\end{array}$ & $\begin{array}{l}6.2 \\
6.3\end{array}$ & $\begin{array}{l}5.0-9.0 \\
5.8-7.1\end{array}$ \\
\hline $\mathrm{F} 3$ & $\begin{array}{l}1 \mathrm{Sec} \\
\text { Burst }\end{array}$ & $\begin{array}{l}6.9 \\
6.7\end{array}$ & $\begin{array}{l}6.7 \\
6.7\end{array}$ & $\begin{array}{l}6.1 \\
6.1\end{array}$ & $\begin{array}{l}5.9 \\
5.8\end{array}$ & $\begin{array}{l}5.8 \\
5.8\end{array}$ & $\begin{array}{l}6.2 \\
6.1\end{array}$ & $\begin{array}{l}5.0-8.0 \\
5.5-7.2\end{array}$ \\
\hline $\mathrm{F} 4$ & $\begin{array}{l}1 \mathrm{Sec} \\
\text { Burst }\end{array}$ & 6.3 & $\begin{array}{l}6.2 \\
6.2\end{array}$ & $\begin{array}{l}5.8 \\
6.8\end{array}$ & $\begin{array}{l}5.8 \\
5.8\end{array}$ & $\begin{array}{l}6.6 \\
6.5\end{array}$ & $\begin{array}{l}6.9 \\
6.8\end{array}$ & $\begin{array}{l}5.0-8.0 \\
5.4-7.0\end{array}$ \\
\hline $\mathrm{F} \Xi$ & $\begin{array}{l}1 \mathrm{Sec} \\
\text { Burst }\end{array}$ & 7.1 & $\begin{array}{l}7.3 \\
7.2\end{array}$ & $\begin{array}{l}6.8 \\
6.7\end{array}$ & $\begin{array}{l}7.0 \\
6.9\end{array}$ & $\begin{array}{l}6.7 \\
6.7\end{array}$ & $\begin{array}{l}7.2 \\
7.1\end{array}$ & $\begin{array}{l}6.0-8.0 \\
6.3-7.9\end{array}$ \\
\hline F 6 & $\begin{array}{l}1 \mathrm{Sec} \\
\text { Burst }\end{array}$ & $\begin{array}{l}6.9 \\
6.9\end{array}$ & $\begin{array}{l}6.5 \\
6.5\end{array}$ & $\begin{array}{l}6.7 \\
6.7\end{array}$ & $\begin{array}{l}6.4 \\
6.4\end{array}$ & $\begin{array}{l}6.6 \\
6.6\end{array}$ & $\begin{array}{l}6.4 \\
6.2\end{array}$ & $\begin{array}{l}5.0-8.0 \\
6.0-7.5\end{array}$ \\
\hline
\end{tabular}

* Data for water are shown as a function of hours of water deprivation. All sucrose solution data were collected under 27 h of water deprivation. All empty cells indicate $S$ did not drink under that condition. 
Table 3

Mean Lick Rates and Lick Ranges for Infant Male $\left(\mathrm{I}_{\mathrm{m}}\right)$ and Infant Female $\left(\mathrm{I}_{\mathrm{f}}\right)$ Gerbils for 1-Sec Measures and Lick Bursts of $5 \mathrm{Sec}$ or More*

\begin{tabular}{|c|c|c|c|c|c|c|c|c|}
\hline \multirow[b]{2}{*}{$\mathrm{S}$} & \multirow[b]{2}{*}{ Measure } & \multicolumn{3}{|c|}{ Water } & \multicolumn{3}{|c|}{ Sucrosé } & \multirow[b]{2}{*}{ Range } \\
\hline & & 12 & 24 & +8 & 4 & $16=$ & $32=$ & \\
\hline $\mathrm{I}_{\mathrm{m}} 1$ & $\begin{array}{l}1 \text { Sec } \\
\text { Burst }\end{array}$ & $\begin{array}{l}5.2 \\
5.1\end{array}$ & $\begin{array}{l}5.4 \\
5.4\end{array}$ & $\begin{array}{l}5.6 \\
5.4\end{array}$ & $\begin{array}{l}5.6 \\
5.6\end{array}$ & $\begin{array}{l}5.9 \\
5.7\end{array}$ & $\begin{array}{l}6.0 \\
6.0\end{array}$ & $\begin{array}{l}5.0-7.0 \\
5.0-6.3\end{array}$ \\
\hline $\mathrm{I}_{\mathrm{m}} 2$ & $\begin{array}{l}1 \mathrm{Sec} \\
\text { Burst }\end{array}$ & $\begin{array}{l}5.8 \\
5.3\end{array}$ & $\begin{array}{l}6.0 \\
5.4\end{array}$ & $\begin{array}{l}5.8 \\
5.8\end{array}$ & 5.6 & 5.9 & $\begin{array}{l}5.5 \\
5.8\end{array}$ & $\begin{array}{l}5.0-8.0 \\
5.3-6.1\end{array}$ \\
\hline $\mathrm{I}_{\mathrm{m}} 3$ & $\begin{array}{l}1 \text { Sec } \\
\text { Burst }\end{array}$ & $\begin{array}{l}5.6 \\
5.6\end{array}$ & $\begin{array}{l}5.4 \\
6.4\end{array}$ & 5.7 & $\begin{array}{l}5.1 \\
5.3\end{array}$ & $\begin{array}{l}5.7 \\
5.6\end{array}$ & $\begin{array}{l}5.8 \\
\vdots .8\end{array}$ & $\begin{array}{l}5.0-7.0 \\
5.0-6.0\end{array}$ \\
\hline $\mathrm{I}_{\mathrm{f}} 4$ & $\begin{array}{l}1 \mathrm{Sec} \\
\text { Burst }\end{array}$ & $\begin{array}{l}5.7 \\
5.8\end{array}$ & 5.6 & 6.0 & $\begin{array}{l}5.7 \\
5.7\end{array}$ & $\begin{array}{l}5.6 \\
5.6\end{array}$ & $\begin{array}{l}5.8 \\
5.6\end{array}$ & $\begin{array}{l}5.0-7.0 \\
5.2-6.1\end{array}$ \\
\hline $\mathrm{I}_{\mathrm{m}} \Sigma$ & $\begin{array}{l}1 \mathrm{Sec} \\
\text { Burst }\end{array}$ & 5.8 & $\begin{array}{l}5.6 \\
5.5\end{array}$ & $\begin{array}{l}5.5 \\
5.4\end{array}$ & $\begin{array}{l}5.6 \\
5.6\end{array}$ & $\begin{array}{l}5.7 \\
5.7\end{array}$ & $\begin{array}{l}5.8 \\
5.8\end{array}$ & $\begin{array}{l}5.0-7.0 \\
5.2-6.1\end{array}$ \\
\hline $\mathrm{I}_{\mathrm{f}} 6$ & $\begin{array}{l}1 \text { Sec } \\
\text { Burst }\end{array}$ & $\begin{array}{l}5.6 \\
5.6\end{array}$ & $\begin{array}{l}4.8 \\
4.8 \\
\end{array}$ & $\begin{array}{l}5.4 \\
5.3\end{array}$ & $\begin{array}{l}5.8 \\
5.8\end{array}$ & $\begin{array}{l}6.0 \\
5.7\end{array}$ & $\begin{array}{l}5.9 \\
5.9\end{array}$ & $\begin{array}{l}4.0-7.0 \\
4.7-6.4\end{array}$ \\
\hline
\end{tabular}

* Data for water are shown as a function of hours of water deprivation. All sucrose solution data were collected under 24 h of water deprivation. All empty cells indicate $S$ did not drink under that condition.

momentary lick rates found for adult and infant gerbils offered statistical confirmation for what is evident from a comparison of the data in Tables 1. 2. and 3. namely. that the lick rates of the infants were significantly lower than the lick rates of the adult male and female gerbils $(\mathrm{p}<.05)$. No statistically significant differences were found, however. associated with sex. deprivation. or type of fluid drunk.

In order to test whether the slower lick rate we had obtained in the infant gerbils was truly an age-related function, the infant gerbils were maintained in their test cages on ad lib food and water until they were 68 day's of age. At this time. these Ss were tested again under ths same experimental conditions that had been employed earlier in the experiment. The results of these tests revealed lick rate data that were totally consistent with the lick rate data that had been obtained from the adult gerbils tested earlier in the experiment. Thus. the lowered lick rates observed in the infant gerbils. relative to the faster lick rates that were observed in the adult gerbils. appear to be attributable to immaturity of the nervous system in the infant gerbil. Unfortunately. the results of the present experiment do not permit specification of the exact chronological age at which the infant lick rates are modified into adult lick rates. nor do the present results present information regarding whether the transition from infant lick rates to adult lick rates is a gradual and progressive process. or an abrupt reorganization of the speed of the lick reflex.

The inter- and intra-S constancy of the lick data found for both adult and infant gerbils is consistent with data reported for cats and hamsters (Schaeffer \& Huff. 1965). for rats (Schaeffer \& Premack. 1961), and for rabbits (Schaeffer \& Darid. 1973). in that lick rates in mammals are found to be of a relatively constant rate and independent of sex. hours of deprivation. and type of solution consumed. The differential lick rates found for infant and adult gerbils. however. are not consistent with those reported for infant and adult cats (Schaeffer \& Huff. 1965) or data reported for infant and adult rats (Schaeffer \& Premack. 1961). In those studies. infants and adults of the same species were found to lick at the same rate. The data from the present experiment clearly. show that infant gerbils. unlike other species thus far tested. do not lick at an adult rate. but do so when they become adults. Although the mean lick rates produced by infant gerbils fall within the absolute range of lick values available to adult gerbils, the infant gerbils clearly have a slower mean lick rate than adults. and clearly have a more restricted range of lick rates available to them than do adults.

Because there is a transition from a slower reflexive licking pattern in the infant gerbil to a more rapid reflexive licking rate in the adult gerbil. these animals may well be of significance as experimental Ss to investigators interested in the development of the nervous system and in the mechanisms of neural and synaptic transmission. Identifiable changes in neurochemical and neuroanatomical function that are correlated with the modification in lick-rate behavior that occurs as the infant grows into an adult have at least the potential possibility of adding considerably to our knowledge of the relationship between neurological function and behavior. Investigators who choose to further explore this relationship will certainly wish to examine critically the absolute range of lick-rate values found in adult is infant gerbils. as well as the developmental fashion in which these lick-rate values are altered as the infant matures. Examination of the absolute upper and lower values of the lick ranges in Tables 1. 2. and 3 shows that the absolute lower lick-rate values for adults and infants differed only by approximately .5 lick sec. whereas the absolute upper lick-rate values for adults and infants differed by slightly more than 1 lick sec. It thus appears that the lower lick rates available to the infunt gerbil are subjected to only 
minimal developmental modification as it grows to adulthood. whereas the absolute maximum upper lisk rates available to this animal increase substantially as it matures. If future investigations substantiate that the more rapid lick rates found in adult gerbils are attributable more to an increase in the absolute lick-rate range available to the organism than to a general elevation of momentary lick rate. it may be found that. although the basic lick rate available to this animal is determined by neuroanatomical struiture. factors such as myelinization and improved sy naptic transmission can account for the more extensive lick-rate range available to the adult gerbil.

\section{REFERENCES}

Adolph. E. F. Measurements of water drinking in dogs. American
Journal of Phvsiology, $1939,125,75.86$

Goodrich. K. P. Running speed and drinting rate ds a function of sucrose concentration and amount of consummatory activity. journal of Comparative \& Physiological Psychology. 1960. 53. $2+5-250$

Schaeffer. R. W. \& David. M. Lick rates in New Zealand white rabbits. Bulletin of the Psychonomic Society. 1973. 2. 45-46,

Schaeffer. R. W.. H Huff. R. Lich rates in cats. Psychonomic Science. $1965.3 .377-378$.
chaeffer. R. Wuff. R.

Schaeffer. R. W. \& Premack. D. Licking rates in infant albino rats. Science. 1961. 134.1980-1981.

Smith. $K$. $C^{*}$. Discriminative behavior in animals. In C. P. Stone (Ed.). Comparatice psicitolog?. Englewood Cliffs. N.J: Prentice-Hall. 1951 .

Stellar. E.. \& Hill. J. H. The rat's rate of drinking as a function of water deprivation. Journal of Comparative \& Phrsiological Psychology. 1952, 45. 96-102.

(Received for publication July 16. 1973.) 